Paedagogia Christiana

2/30 (2012) - ISSN 1505-6872

Alicja Żywczok*

Katowice

\title{
Idea afirmacji życia $w$ nauce o naturze Bronisława Ferdynanda Trentowskiego
}

Współczesna recepcja dzieł Bronisława Trentowskiego (1808-1869) jest co najmniej tak samo fascynująca jak ryzykowna. Transcendentalna filozofia napisana jest stylem zawilym na poziomie „odkodowania” znaczenia i przyswajania znaków, gdyż autor nawiązywał do staropolszczyzny (wręcz chlubił się archaizmami). Jednak pod etykietą niecodziennych zwrotów kryją się pionierskie myśli, godne odsłonięcia i asymilacji. Swoboda stylistyczna w wyrażaniu najgłębszych refleksji i odkrywczych idei, dla których Trentowski znajdował nowe środki wyrazu, rodziła ekspresję językową charakterystyczną dla ówczesnego polskiego filozofowania.

Niniejszy tekst jest sposobem udowodnienia, że to, co minione, nie musi być zapomniane lub zmumifikowane. Odległe historycznie teksty mogą wciąż budzić zainteresowanie nie tylko zawartym w nich przesłaniem, swoją treścią, ale również strukturą, logiką i stylistyką narracji. Wysiłek „,przełożenia" zawartości merytorycznej takich dzieł po to, by udostępnić je współczesnym użytkownikom kultury, okazuje się ważny zarówno ze względu na znajomość dziejów kultury, jak i wypracowany przez pokolenia przekaz mądrości pedagogicznej. Transkrypcja myśli pedagogicznej Bronisława Trentowskiego może służyć lepszemu rozumieniu wielu bieżących problemów społecznych i wychowawczych oraz optymalnemu ich rozwiązywaniu.

* Dr Alicja Żywczok, adiunkt w Katedrze Teorii Wychowania Instytutu Pedagogiki Uniwersytetu Śląskiego w Katowicach. 


\section{Radość fundamentalnego porządku i jedności wszechświata}

Głównym przedmiotem afirmowania życia przez człowieka jest środowisko przyrodnicze, nazywane przez Bronisława Trentowskiego „naturą”. Ludzką afirmację wszechświata pobudzają zwłaszcza specyficzne właściwości tejże natury, a mianowicie jej: jedność, celowość, różnorodność, uporządkowanie (organizacja), piękno, rozumność i praworządność. Cechy te są zarazem dyspozycjami człowieka, jak i Stwórcy. Perfekcyjna precyzja dzieł stworzenia oraz afirmujący je człowiek są najlepszymi dowodami na istnienie boskiej kreacji, a także na istnienie wyodrębnionego z tychże dzieł natury ludzkiego „Ja”.

Jedynie we wszechświecie panuje całkowita jedność, która jako taka posiada swój określony początek, swój punkt środkowy i koniec; w nim wszystko znajduje się w systematycznym powiązaniu, tworząc ogół - jedyne, celowe, filozoficzne uniwersum [...]. Wszystko jest uduchowione i duchem przepełnione. Sceptyk, który podaje w wątpliwość swoje myślenie, zasługuje jedynie na współczucie. Dla sceptyka zarówno własne uczucie, jak i własne myślenie jest pozorem. Bezpośredniość wiedzy o swoim Ja nie może mu zostać dowiedziona, ponieważ można ją tylko odczuć. Wprawdzie Kant, filozof empiryczny, udowadnia istnienie samowiedzy za pomocą istnienia świata zewnętrznego, jednak istnienie świata zewnętrznego nie daje się w inny sposób udowodnić, jak tylko za pomocą istnienia samowiedzy. Wszystko, co bezpośrednie, nie daje się udowodnić, może być tylko odczute. Człowiek odczuwa bezpośrednio zarówno obecność świata zewnętrznego, jak i samego siebie [...]. Zgodnie z maksymą kartezjańską, to dzięki rozumowi, a nie dzięki świadectwu świata zewnętrznego czy świadomości poznawczej, człowiek wie, że istnieje, a więc wie o tym wprost $\mathrm{z}$ samego siebie. Wiedza ta stanowi niewzruszony wspornik jego poznania metafizycznego ${ }^{1}$.

Prestabilność i okazjonalizm są w filozofii przyrody Trentowskiego istotnymi aspektami celowości natury. Prestabilność jest rodzajem wewnętrznej dzielności (Virtuosität) rzeczy, która popycha jednostkowość do osiagnięcia swego celu, a zarazem grozi popadaniem jednostkowości w kolizję z celowością zewnętrzną, czyli z okazjonalizmem. Na przykład żołądź jest wielkim dębem w zarodku, wystawionym na wszelkie możliwe kaprysy losu, czyli

${ }^{1}$ B. Trentowski, Podstawy filozofii uniwersalnej. Wstęp do nauki o naturze, Warszawa 1978, s. 105, 144, 145. 
jest dębem in potentia. Z góry ustalonym celem żołędzi, czyli ich prestabilnością, jest stać się wielkim dębem. Żołądź natrafia czasem na przeszkody, na przykład złą pogodę, przeniesienie w inne środowisko lub uszkodzenie. W ten sposób uwidocznia się walka konkretnej prestabilności z określonym okazjonalizmem, w wyniku której następuje albo triumf prestabilności, albo zwycięstwo okazjonalizmu. Nie istnieje również celowość zewnętrzna (ogólna) bez celowości wewnętrznej (jednostkowej). W ten sposób wszystko, co istnieje w naturze, jest jednocześnie środkiem i celem. Rdzeń takiej teleologii Trentowskiego znajdujemy w przemyśleniach zawartych w jego dziele: Podstawy filozofii uniwersalnej. Wstęp do nauki o naturze.

Subtelną relację między celowością wszechświata a boską mądrością można uchwycić w następującym fragmencie źródeł naukowych:

nie tylko w istocie człowieka, ale w całej naturze pokazuje się mądrość boska kierująca systemami słonecznych światów, rozwijająca się we wnętrznościach i na powierzchni ziemi, tworząca kamienie drogie i kruszce, królestwa flory i fauny, odsłaniająca wszędzie pełno elizejskich tajemnic, a wreszcie godną podziwiania ogólną celowość wszechrzeczy [...]. Wielka, wszystko wiążąca siła przepełnia powszechne istnienie i występuje w najróżniejszych postaciach. Ona wiedzie kropelkę do kropelki, żyjątko do żyjątka i spaja je z sobą jako magnetyzm, krystalizacja, polarność, a także jako pokrewieństwo, pociąg, sympatia i cnota [...]. Każdą istotę, wszystko, co nas otacza, pragniemy przytulić śród radości do naszego serca; cała natura nam żyje, jest matką nasza, a my rzucamy się z rozkoszą w serdeczne jej objęcia. Nie są że te przedmioty z naszym, podmiotowym uczuciem polaryzujące? Widzimy, jak światło słoneczne z głębokości ziemi ciepło wywołuje i z nim się ożeniwszy płodzi ogień złoty, stający się ogólnego istnienia na naszej planecie rajskim żywiołem. Każda roślina wyciąga, jak dziecię do ojca, do słońca swe ramiona, rośnie swobodnie pod jego okiem i dobroczynnym wpływem. Dojrzawszy wreszcie i rozpaliwszy się miłością, wydaje owoc i powierza go z ufnością troskliwości swego ojca. Cały ten wpływ wiecznie młodego i nadobnego Apollina na Dafne nie ma na celu wydarcia jej z objęć matki ziemi. [...] Mądrość boska znajduje w naszym sercu swe ognisko i wierne zwierciadło ${ }^{2}$.

Dosłowne przytoczenie słów Trentowskiego wynika z przeświadczenia, że wierne oddanie przesłania, połączone z uczciwością przekazu niezniekształconego przez swobodną interpretację kolejnych naśladowców i kon-

2 Tenże, Chowanna, czyli system pedagogiki narodowej jako umiejętności wychowania, nauki i oświaty, słowem wykształcenia naszej młodzieży, t. I, Wrocław-Warszawa-Kraków 1970, s. $458,460$. 
tynuatorów spuścizny tegoż filozofa i pedagoga, posiada dodatkowy walor naukowy: oddziaływanie poznawczo-emocjonalne pobudzające do studiów i rodzące zamiłowanie filozofią wychowania. „Każda interpretacja niesie ze sobą ryzyko oddalenia faktycznego rozumienia i kontaktu z samym dziełem, zgodnie zresztą z przestrogą Martina Heideggera, że przedstawianie jest to podstawianie, zastępowanie, naznaczone redukcją i licznymi zabiegami zestawiania"3.

Celowość natury i jej harmonia wynikająca z uporządkowania wielości elementów, jak również twórcza różnorodność, mogą wzmacniać ludzkie przeżywanie afirmacji życia poprzez uczucia zachwytu, podziwu, zdziwienia i zdumienia, które wywołuje w swoich adoratorach. Można jednak sądzić, że tylko człowiek ceniący ową celowość, harmonię i różnorodność, a ponadto otwarty zmysłowo, uczuciowo i deontycznie na takie doświadczanie świata, będzie cechy te spostrzegał i uznawał za istotny powód afirmowania życia. Nie każdy przecież przebywając na łonie natury odczuwa ją w taki sam sposób; jeden w ogóle nie zauważa szczegółowych aspektów piękna świata, drugi przyglądając się swemu przyrodniczemu otoczeniu mógłby wypowiedzieć, przykładowo, takie oto słowa:

pradawna i wiecznie młoda różnorodność znajduje się wszędzie i wokół nas, a jej prawda i rzeczywistość są również aposteriorycznie zapewnione. Popatrzmy tylko w naturę! Jakie postaci, jakie formy, jakie barwy przybiera tam nieziemski i nieokreślony powiew metafizycznego i przedkreacyjnego Absolutu. Jak różnorodne jest np. wspaniałe piękno gwiaździstego nieba, cóż za łabędzie chmury płyną przez niebieskie morze eteru, jaką grą barw mienią się ciche narodziny Aurory, jak liczne i różne są wiosenne dzieci Flory, jak liczni i odmienni są mieszkańcy łąk, lasów, wód, powietrza! A ród ludzki! Jak różnorodne oblicza nadaje Amor młodości strojnej pięknem poranka życia [...]. Jaka różnorodność rysów w obliczach Achillesa i Tersytesa, Chrystusa i Judasza, Tassa i chciwego na złoto kramarza. Gloria genialności i świeczka łojowa pospolitości - obie goreją światłem, ale jakaż różnica $w$ ich promieniowaniu? Ciężarna deszczem chmura roni wodę, która spada z nieba perłami kropel, ale żadna kropla nie jest równa innej. Wielkie drzewo dźwiga miliony liści, jednak jeden liść nie jest drugiemu równy. Lud zbiera się, aby wziąć udział w powszechnym święcie narodowym. Ile tysięcy ludzi! Ale czy choć jeden człowiek jest taki sam jak drugi? Duch jest absolutną jednością, a jednak - jako wewnętrzny wszechświat

${ }^{3}$ L. Witkowski, Przedmowa. Koniec alibi dla wykluczenia, w: W. Andrukowicz (komentarz, wybór i opracowanie), Bronistaw Ferdynand Trentowski. Chowanna (myśli wybrane), Kraków 2010, s. 9. 
we wszechświecie - jest tak różny w swoich momentach [...]. Różnorodność świata jest nieskończona, a więc nie zamknie się w żadnej ramie ${ }^{4}$.

Piękno natury nie tylko pozwala poznać właściwości jej twórcy, ale również inspiruje człowieka do ukazania swojego człowieczeństwa. Ludzka wrażliwość estetyczna objawia się najsilniej w dbałości o los przyrody, jej przetrwanie i podtrzymanie między człowiekiem a innymi organizmami relacji symbiotycznych.

Stylistyka oparta na licznych pytaniach stawianych przez Trentowskiego czytelnikowi tychże dzieł jest dowodem jego wychowawczego zamysłu i chęci obudzenia w odbiorcy refleksyjności typowej dla miłośnika życia. Skłonienie innych do filozofowania w obrębie proponowanych zagadnień miała przynieść wymierne rezultaty w postaci odczucia zjednoczenia ze światem i dopracowania się postawy sympatii dla życia.

Czy widzisz niezmierzone srebrne pasma niebiańskich dróg mlecznych z ich niezliczonymi planetami, tajemniczego sfinksa nocy, która tak łagodnie uśmiecha się do ciebie swoim gwiezdnym obliczem? Czy widzisz dumnego władcę dnia, który uszczęśliwia cię życiodajnym światłem i wdzięcznym ciepłem? Czy widzisz chmury, owe latające oazy nieba, góry - niewzruszone maszty ziemskiego statku, a także sam ów statek i wszystkie kamienie szlachetne, które go wypełniają? Czy widzisz skupiska lasów i ogrodów z ich kwiatowymi rozpadlinami, niewiarygodne królestwo zwierząt, kolumny marszowe owadów rozwieszone w każdym promieniu światła dziennego i ów przepych życia i radości, która cię ze wszystkich stron otacza? Wszystko to jest objawieniem człowieka ${ }^{5}$.

Czy słyszysz pianissimo brzęczenia komara i fortissimo gromu, nastrojowe tony słowików i basy orkanów? Czy słyszysz radosny okrzyk wiosny i modlitewny pomruk zimy, delfickie hymny lata i bachiczne nawoływania jesieni? Słyszysz to wszystko, ale to tylko jeden ton z mojego rogu. Czego nie słyszysz, to mojej muzyki sfer, śpiewu planet, hosanny wszechświata, opery bezkresnego istnienia. Wszystko to jest moją mową, ta zaś opowiada tysiącami ziemskich głosów, kim jestem ${ }^{6}$.

Wszechświat nie jest nieuporządkowany i chaotyczny, lecz powiązany i zorganizowany, jest systemem.

\footnotetext{
${ }^{4}$ B. Trentowski, Podstawy, s. 662, 663.

5 Tamże, s. 348.

${ }^{6}$ Tamże, s. 349.
} 
Natura działa zawsze mądrze, a człowiek prawie zawsze niemądrze, natura jest więc zawsze rozumna, a człowiek prawie zawsze nierozumny? Jedyny słuszny wniosek, jaki można wyciagnąć z milczącej i mądrej działalności natury oraz z krzykliwej i zarozumiałej duchowości człowieka, brzmi, że w naturze ujawnia się rozum Boga w stężeniu, czyli w swojej konieczności, a w człowieku ten rozum ujawnia się w skropleniu, czyli w swojej samowoli, jednakże w obu wypadkach jest to w gruncie rzeczy ten sam rozum ${ }^{7}$,

jak zapisał nie bez racji Bronisław Trentowski.

Ostatnia z opisywanych właściwości natury - praworządność posiada swoje ścisłe powiązanie zarówno z różnorodnością przyrody, jak i afirmacją życia dokonującą się za jej pośrednictwem. „Dzięki praworządności odnawia się różnorodność w naturze, np. praworządność ciała niebieskiego pogrążonego w falującym rytmie walca. Walc ten, jakkolwiek wywodzi się z dynamicznego źródła, jest prawom mechaniki posłuszny i przyczynia się do ich ewolucji. Praworządność czasami neguje różnorodność, bo każda psychika neguje swą somatykę. Negacja ta jest jednak także zachowywaniem, afirmacją"

Współczesny człowiek coraz silniej poddaje się tendencji do instrumentalnego traktowania przyrody połączonego często z utratą odczucia zjednoczenia z nią. Ów brak emocjonalnej bliskości z dziełami natury jest jednym z niepokojących przejawów zdziczenia9 ${ }^{9}$ dehumanizacji nie tylko jednostek ludzkich, ale całych społeczności. Człowiek przebywający głównie wśród wytworów cywilizacji zdaje się nie spostrzegać wychowawczych, profilaktycznych i terapeutycznych atrybutów natury. Dodatkowo, rzadko obcując ze środowiskiem naturalnym, traci orientację wewnętrzną i słabnie jego doznawanie procesu życia. W takim sposobie istnienia kolejnych pokoleń można doszukiwać się przyczyn eskalacji wielu zagrożeń indywidualnych i społecznych.

\section{Wyróżniki czlowieka i odmienność jego sposobu afirmowania życia}

Człowiek - w filozofii Bronisława Trentowskiego - jest nie tylko celem stworzenia, ale jego zwieńczeniem, najpełniejszym dziełem Stwórcy, dziełem zarazem materialnym i niematerialnym. Jednostka uczestniczy w cało-

\footnotetext{
7 Tamże, s. 655, 676.

8 Tamże, s. 677.

9 Por. A. Nalaskowski, Dzikość i zdziczenie jako kontekst edukacji, Kraków 2006.
} 
ści natury, natura natomiast jest reprezentacją tego, co jednostkowe. Istota człowieka, a więc jego człowieczeństwo, jest święte i za takie powinno się je uważać. Jako istota obdarzona najwyższą wśród innych bytów świadomością doświadcza także odmiennych rodzajów przeżyć, a mianowicie duchowych, takich jak: miłość, serdeczność i szczęśliwość.

Oto, w jaki sposób ten osadzony temporalnie jeszcze w epoce romantycznej, a myślący oświeceniowo pedagog opisuje doniosłość osoby ludzkiej:

człowiek jest szczytem i koroną świata zwierzęcego, a zatem i całego stworzenia. Musi więc ogarniać wszystko, co było przed nim, tak jak w owocu mieszczą się wszystkie części rośliny. Człowiek jest pomniejszoną całością natury, a cała natura nie jest niczym innym jak człowiekiem rozłożonym na czynniki i ukazanym w swoich poszczególnych momentach. W człowieku wrażliwość staje się myśleniem, pobudliwość - czuciem, siła reprodukcyjna - pożądaniem, zaś absolut staje się w nim duchem [...]. Człowiek jest ostatnim ogniwem objawienia. Twierdzenie to ma swoją podstawę przede wszystkim w naturze. Jak długo bowiem żyjemy w naturze i staramy się ją zbadać, tak długo nie możemy odkryć żadnej doskonalszej materialności niż ciało człowieka. Natura nieorganiczna wznosi się po niezliczonych stopniach rozwoju, aż w końcu staje się organiczna, a natura organiczna przechodzi przez swoje niezliczone stadia, by stać się nieorganiczną i duchową ${ }^{10}$.

Niemal doskonała materia człowieka znajduje dopełnienie w niematerialności i wrażliwości duchowej. Koincydencja materialności i duchowości ludzkiej pozwalają posłużyć się w stosunku do niego określeniem ,święty”.

Święta jest istota człowieka, ona bowiem jest wnioskiem końcowym, ekstraktem świętej całości. Jak jednak całość tkwi w jednostkowości, tak również jednostkowość tkwi w całości. Pojedynczy człowiek nie może w ogóle egzystować bez Boga, natury, żywiołów i wielu innych rzeczy. Bez swoich współbraci jest żebrakiem. Stoik, który oddala się od ludzi w myśl dumnej zasady samowystarczalności oraz eremita, który ucieka na pustynię w imię fałszywie pojętej pobożności, szybko przestają być ludźmi. Tylko na łonie ludzkości można być człowiekiem [...]. Jednakże nie tylko w człowieku, lecz także we wszystkich rzeczach, bez wyjątku, wyraża się całość i nie tylko człowiek, lecz także wszystko, co jednostkowe, tkwi w całości ${ }^{11}$.

\footnotetext{
${ }^{10}$ B. Trentowski, Podstawy, s. 41, 459.

11 Tamże, s. 654, 655.
} 
Zastosowane przez Trentowskiego finezyjne metafory w deskrypcji cech konstytutywnych człowieka okazały się nieprzypadkowe. Liczne i jakże trafne określenia człowieka, między innymi jako: „szczyt” i „korona” świata zwierzęcego, ostatnie „ogniwo stworzenia”, „ekstrakt całości”, ukazują miejsce człowieka we wszechświecie, a zarazem konstruktywny sposób wartościowania innych form życia. Istnienie człowieka potraktowane przez niego samego jako zobowiązanie do uszanowania mikro- i makrostruktury kosmosu jest najdoskonalszym rodzajem jego odpowiedzi na stwórczą aktywność. Ludzka postawa odpowiedzialności nie przestaje być aktualna, godnościową reakcją na dar życia i koegzystencję człowieka z otaczającą go materią.

Proces powoływania człowieka do istnienia pod względem kreatywności nie ma sobie równych. Żadna współczesna przemiana życia społecznego ani nawet największe udoskonalenia techniczne nie mogą dorównać twórczemu kształtowaniu natury ludzkiej. Kształtowanie to ma postać gigantycznej reformy.

Człowiek jest celem ostatecznym całej natury, stąd też wszystkie inne rzeczy są tylko środkami do wytworzenia człowieka. Słońce, planety, królestwa i wszystkie rzeczy natury musiały zostać stworzone, zanim człowiek mógł zobaczyć światło dzienne i powiedzieć: jestem! Jaki to przykład stwórczej mądrości dla ludzi, jaki przykład postępowania i wstyd dla dzisiejszych reformatorów świata. Chociaż człowiek jest celem ostatecznym natury, a wszystkie pozostałe rzeczy są tylko środkami do tego celu, każda rzecz bez wyjątku jest również celem ${ }^{12}$.

Na duchowość jako główny wyróżnik człowieka na tle innych organizmów żywych, a równocześnie generator zasadniczych różnic w ich sposobach afirmowania życia, wskazuje Trentowski w następującej wypowiedzi:

wszystko, co istoty od człowieka niższe nieświadomie czują, czuje także człowiek, ale świadomie, stąd też bez porównania silniej. Świadomości tej przyczyną jest jego duch [...]. Jagnię skacze sielskim tańcem po swej łące, gryzie trawę, która mu smakuje, szuka strumienia w pragnieniu, a nasyciwszy się fizycznie, spoczywa i zasypia. To jego rozkosz cała. Ale zupełnie innym uczuciem jest owo zachwycenie, owa szczęśliwość estetyczna, której człowiek doznaje, znalazłszy np. śród wulkanów skalistej Islandii pozbawionej prawie wegetacji, widząc dolinę zaczarowaną, a w niej cytrynę, pomarańczę, kwiaty i wszystkie cuda południowego nieba lub też idąc śród niw litewskich, kołyszących się fa-

12 Tamże, s. 726. 
lami morza pszenicy albo patrząc z niebotycznej góry na odległe okolice: miasta, wsi. My kładziemy się inaczej od zwierza na serce pięknej i zajmującej nas natury. Rzeczy ziemskie nabierają tu natury niebiańskiej, przyjemność fizyczna przemienia się w przyjemność moralną, skok w taniec, głos w ton i muzykę, blask i barwa w nadobne postaci, proste wrażenia w umysłu ideały [...]. To jest przyczyną wyższej przyjemności, której na łonie natury doświadczamy. Człowiek raduje się tworząc, jak jego ojciec w niebie. Nasza miłość i nasza serdeczność ma też niebiańskie piętno. My kochamy wszakże nawet oderwane myśli, nawet pamięć dawnych przodków. Każdy człowiek lepszy czyni uroczystą przysięgę, że wiecznie kochać będzie człowieczeństwo. Każdy tęskni i gna za miłością innych ludzi i znajduje w tej miłości szczęście i rozkosz niewypowiedzianą [...]. Szczęśliwy i nieszczęśliwy, kto czuje silnie i ma ogniste serce $^{13}$.

Specyfika ludzkiego przeżywania afirmacji życia przejawia się poprzez szczególną więź międzyludzką oraz delikatność relacji człowieka z przyrodą ożywioną i nieożywioną. Kognitywne, uczuciowe, moralne i duchowe podłoże doświadczania afirmacji życia u człowieka czyni ten rodzaj przeżyć rdzennie ludzkim i zasługującym na chronienie między innymi przez skonsolidowane wysiłki wychowawcze różnych podmiotów życia zbiorowego. Rozwój ekofilozofii i ekoetyki oraz edukacji ekologicznej może sprzyjać kształtowaniu takiej wrażliwości u dzieci i młodzieży, która będzie predysponować ich do przejawiania aksjologicznie prawidłowej postawy afirmacji życia.

\section{Dobre wychowanie jako największe szczęście człowieka}

„Szczęśliwy, kto otrzymał dobre wychowanie”14 - oto główna teza felicytologicznej warstwy systemu wychowania Bronisława Trentowskiego. To stwierdzenie skłania zarówno do zastanawiania się nad tym, czym jest tak zwane dobre wychowanie, jak również do namysłu nad właściwościami człowieka szczęśliwego i warunkami prowadzącymi go do szczęścia. Zachowanie wewnętrznego spokoju i przezwyciężanie niepomyślnych zdarzeń losu, a ponadto uodpornienie dzieci i młodzieży na trudy życia poprzez zwalczanie bezczynności i wypracowanie hartu ducha, to tylko niektóre z zalecanych przez tego filozofa technik osiagania zadowolenia z życia. Nie bez

\footnotetext{
13 Tenże, Chowanna, t. I, s. 460, 461.

${ }^{14}$ Tenże, Chowanna, t. II, s. 529.
} 
znaczenia w kształtowaniu postawy afirmacji życia jest również nabycie we wczesnym dzieciństwie przyzwyczajenia do przeżywania radości i wesołości, nawet w sytuacji dyskomfortu fizycznego lub psychicznego. Podstawową przyczyną życiowych nieszczęść jest, poza niesprzyjającymi okolicznościami losowymi, zwyczajny brak rozumności i rozwagi.

Wewnętrzny spokój sprzężony z postawą mądrości, w przekonaniu Trentowskiego, stanowi najpewniejsze wyposażenie wychowanka prowadzące go do poczucia szczęścia.

Spokojność umysłu to obraz życia ludzi cnotliwych. Szczęśliwe dziecko, które już w domu rodzicielskim życiem tym żyło [...]. Człowiek prawdziwy kocha ludzkość, szanuje wolę Boga, działa mądrze, cieszy się usiłowań swych owocem, a zewnętrznym jego znamieniem jest moralna, religijna lub filozoficzna spokojność. Spokojność ta jest zlaniem się ponurości i wesołości w jedno, jest umysłu błogością, najwyższą szczęśliwością, niebem na ziemi. Człowiek spokojny, w powyższym wyrazu tego znaczeniu, nie jest odrętwiały na dobre lub złe objawiające się śród społeczeństwa, nie szuka swego szczęścia w bezczynności. Walczy za dobrem. Spokojność umysłu nie jest ani tybetańską próżniaczą ciszą, tym wiecznym odpoczynkiem umarłych zrobionym za cel dla żyjących, ani arystypową lekkomyślnością, ani stoicką apatią, czyli obojętnością na rzeczy ziemskie, ale jest ona jaźni mającej czyste sumienie, uwielbienia stanem. Jest to spokojność chrześcijańska, korona najwyższej cnoty. Jak ponurość lub wesołość, tak i spokojność umysłu udzielić innym możesz, skoro sam ją posiadasz. Wychowuj dzieci twe do tej Bożo-człowieczej spokojności mędrca, a zapewnisz im szczęście ${ }^{15}$.

Formujący się charakter młodego człowieka potrzebuje wielu wolicjonalnych bodźców do rozwoju, a zatem, jak radzi Trentowski,

wychowuj twe dzieci tak, żeby w każdym położeniu szczęśliwymi być mogły. W bogactwie i ubóstwie, wolności i niewoli, we wszystkich humorach dziwacznego losu niechaj nie traca głowy i znaleźć się rozumnie umieją! Wczoraj byłeś panem, dziś jesteś sługą, to losy nasze. Ale wczoraj i dzisiaj wesół jesteś? Po co się smucić, gdzie rzeczy odmienić niepodobna. Nieszczęście jest duszącą nas zmorą. Ruszmy się silnie i wesoło, a zmora przepadnie [...]. Szczęście nasze żyje w nas, w naszej silnej woli [...]. Nie do zewnętrznego eudajmonizmu, ale do wewnętrznego stoicyzmu masz dzieci twe wychować! Słaby tańcuje, jak mu los zagra, dusza silna zmusi los do innej muzyki. Dziecię twe niech będzie

15 Tamże, s. 638, 629. 
nowym Spartaninem [...]. Nie wiemy, co je czeka; czy mu śmiejąca się Pafii wdziękiem, czy też piorunami ciężarna przyszłość zaświta. Kto chleb razowy jadał dziecięciem, temu później smakować będą marcepany, ale nie odwrotnie: kto grubą litewską burką się odziewał, ten przyzwyczai się wnet do fraka, ale panicz odbierze sobie zniewieściały żywot, nim ubierze się w podlaski samodział [...]. Dzieci twe niech uważają życie jako krótką, ale niebezpieczną podróż morską, niechaj będą ustawicznie na burze i wreszcie na rozbicie okrętu przygotowane. Śmierć przychodzi zawsze pierwej, nim się jej spodziewaliśmy, przychodzi nie meldując się i nie pukając w nasze podwoje $\mathrm{e}^{16}$.

Nawet jeżeli wychowanek doskonale znosi trudy życia i potrafi z godnością zachować się w nieszczęściu, to nie oznacza jeszcze, iż nie potrzebuje systematycznych wzorców przeżywania radości życia i satysfakcji. Ten problem wychowawczy dostrzega Trentowski, pisząc: ,niejeden jest rycerzem wśród harców cierniowych nieszczęścia, ale topi się jak masło w promieniach słońca. Nie tylko do trudu i wojny, ale także do radości i wesela przyzwyczaić się trzeba"17.

Proces równomiernego uruchamiania pozytywnych właściwości człowieka, a przy tym minimalizowanie destruktywnego oddziaływania klęsk życiowych i wszelkiego rodzaju nieszczęść, decyduje w znacznej mierze o powodzeniu procesu wychowania. Błędne okazuje się wychowanie, którego realizatorzy albo bagatelizują trud życia, albo imputują swoim wychowankom lęk przed życiem. Równie niedoskonałe i jednostronne okazuje się również wychowywanie dzieci jedynie do przeżywania pomyślności życiowej.

\section{Podsumowanie}

1. W filozofii wychowania Bronisława Trentowskiego zdolność afirmowania życia wyraża się między innymi w konstruktywnym spostrzeganiu i przeżywaniu określonych właściwości wszechświata, a mianowicie jego: jedności, celowości, różnorodności, uporządkowania, piękna, rozumności i praworządności. Człowiek świadomy hojności bytu staje się aktywnym podmiotem wychowania i samowychowania, w którym zaczynają egzystować liczne jednostki aksjologiczne, zwłaszcza zaś wdzięczność, pokora, zdumienie życiem, szacunek i miłość.

2. Współczesna denaturalizacja i deheroizacja życia przejawia się między innymi jako utrata pierwotnej postawy egzystencjalnej człowieka - re-

\footnotetext{
16 Tamże, s. 122, 136.

17 Tamże, s. 122.
} 
werencji dla życia. Silne osadzenie współczesnego człowieka w cywilizacji i technosferze utrudnia mu kontakt z naturą i rodzi atrofię potrzeby obcowania z nią. W tej sytuacji zjednoczenie człowieka ze światem nie jest prozaicznym zadaniem wychowania. Wychowawcom pozostaje albo kształtowanie u uczniów dbałości o zachowywanie proporcji między czasem spędzanym w środowisku naturalnym i stechnicyzowanym, albo przywracanie już zachwianej w tym zakresie równowagi. Ważne, by zarówno wysiłki wychowawcze, samowychowawcze i autokreacyjne człowieka skierowane były na jego rozwój odbywający się nie tylko za pośrednictwem nowoczesnych technologii informatycznych, ale również z udziałem kształcących oraz profilaktycznych i terapeutycznych walorów natury. Taki rezultat procesu wychowania, jak uzyskanie homeostazy między afirmacją natury a afirmacją technicznych udogodnień, można nazwać pomyślnym.

3. Odmienność ludzkiego sposobu afirmowania życia, w porównaniu z innymi organizmami żywymi, przejawia się poprzez wyjątkowe przeżycia duchowe człowieka, takie jak: miłość, serdeczność i szczęśliwość. Do afirmowania makro- i mikrokosmosu predysponuje osobę ludzką również jej naturalna wrażliwość emocjonalno-moralna.

4. Podstawowym źródłem afirmacji życia młodego człowieka jest prawidłowy proces wychowania, realizowany przez pierwszych wychowawców dzieci i młodzieży: rodziców, opiekunów i nauczycieli. Dobrym nauczycielom jako orędownikom szczęśliwego życia swoich podopiecznych przypisuje Trentowski pewien rodzaj psychologicznej ,niepodległości”, który pozwala im wychowywać uczniów w zgodzie z własnym sumieniem i wielopokoleniowymi osiągnięciami pedagogicznymi.

\section{The Idea of Affirmation of Life in Bronisław Ferdynand Trentowski's Teachings about Nature (Summary)}

The intention of the author of this paper is to remind us about the classical idea of affirmation of life included in Bronisław Ferdynand Trentowski's philosophy of education and his teachings about nature. This philosopher argues that the ability of affirmation of life is expressed, among others, in the constructive perception and experiencing of certain properties of the universe, such as its unity, purposefulness, diversity, order, beauty, rationality and the rule of law. Human affirmation of life is different in that it manifests itself through a unique emotional and moral sensitivity and spiritual experience of man, such as love and happiness. The author refers to one 
of the original theses proposed by Trentowski, according to which the fundamental source of affirmation of life by a young person is the correct process of upbringing and education, carried out by the first educators of children and young people, i.e. their parents, guardians and teachers. 